\title{
Perancangan Program Pengelolaan Transaksi Pembelian dan Penjualan Perlengkapan Olahraga Pada Abadi Sport
}

\author{
Dede Nurahman ${ }^{1}$ Feri Prasetyo $\mathrm{H}^{2}$ Eka Pratama ${ }^{3}$ \\ STMIK Nusa Mandiri ${ }^{[1]}$ AMIK BSI bekasi ${ }^{[2]}$ AMIK BSI Karawang ${ }^{[3]}$ \\ Program Studi Sistem Informasi Program ${ }^{[1]}$ studi Manajemen Informatika ${ }^{[2][3]}$ \\ e-mail: dedenurrahman@gmail.com ${ }^{[1]}$ feri.fpo@bsi.ac.id ${ }^{[2]}$ ekaprata0811@bsi.ac.id ${ }^{[3]}$
}

\begin{abstract}
Abstrak- Sistem Pembelian dan Penjualan Barang merupakan sistem yang memberikan kegiatan layanan informasi berupa kegiatan kegiatan transaksi pembelian, data dan penjualan barang dan stok barang. Keberadaan sistem informasi ini penting. Dalam hal ini, Abadi Sport merupakan sebagai tempat penelitian, karena sistem pembelian dan penjualan barang di tempat belum dikelola dengan baik banyak kasus yang terjadi sehingga sering terjadi kesalahan dalam pembuatan laporan yang ada, penyimpanan data yang tidak efektif dan efisien karena hanya diarsipkan begitu saja. Sehingga menyulitkan pencarian data, bentuk yang faktur mirip dengan menyebabkan kesalahan dalam Perekaman, penyajian informasi yang lambat ketiaka akan dibutuhkan oleh pimpinan. Metode yang digunakan adalah bahasa pemrograman terstruktur dan metode pengembangan perangkat lunak dengan menggunakan model waterfall. Metode pengumpulan data yang digunakan adalah menggunakan metode observasi, wawancara, studi pustaka. Alat analisis yang digunakan adalah Use Case Diagram, Activity Diagram, Entity Relationship Diagram (ERD), Logical Record Structure (LRS). Perangkat lunak yang digunakan adalah: NetBeans IDE 8.1, java 1.7.7, dan Xampp 1.7.7. Rancangan program ini dibangun untuk memberikan kemudahan dalam memproses pembelian dan penjualan data baik dari pembelian ke pemasok dan penjualan ke pelanggan serta laporan pengolahan pembelian dan penjualan menjadi lebih tepat dan akurat.
\end{abstract}

Kata Kunci-Program Design, Purchasing and Sales Program

\section{Pendahuluan}

Perkembangan perangkat keras komputer dengan segala kecanggihannya membawa dampak positif dan negatif dalam dunia bisnis informasi. Dampak positif dari adanya komputer adalah proses data dan informasi yang menjadi tulang punggung dunia bisnis dapat dilakukan dengan cepat, tepat waktu, dan akurat. Sedangkan dampak negatifnya adalah timbulnya kejahatan penyelewengan dari penggunaan perangkat keras tersebut. Akan tetapi, terlepas dari semua itu bahwa kemajuan teknologi komputer yang dapat mendukung pengolahan informasi menjadi alat pemicu persaingan dunia bisnis dan ekonomi yang semakin kompetitif.

Abadi Sport, yaitu sebuah usaha perdagangan yang menyediakan perlengkapan olahraga, didirikan oleh Bapak
As'ari pada tahun 2009 yang kegiatan utamanya adalah membeli barang dagang dengan jumlah banyak untuk dijual kembali dengan harapan untuk mendapatkan keuntungan atau laba tanpa melakukan perubahan terhadap barang tersebut. Melihat perkembangan gaya hidup berolahraga yang begitu cepat. Abadi Sport menjadi salah satu tempat favorit bagi konsumen untuk mencari perlengkapan olahraga yang berkuaitas, lengkap, dan tentunya dengan harga murah.

Dalam dunia usaha seperti usaha perdagangan erat kaitannya dengan transaksi pembelian dan penjualan, yang kegiatan utamanya selalu berhubungan dengan pengolahan data, maka sangat dibutuhkan komputer untuk penyediaan informasi yang cepat dan mempermudah mengorganisasikan data-data yang masuk maupun transaksi yang tercatat. Dengan bantuan sebuah komputer, kegiatan penyimpanan data maupun transaksi tidak lagi dilakukan diatas kertas yang menghabiskan cukup banyak tempat penyimpanan, serta bisa mengurangi kehilangan data.

Adapun contoh permasalahan yang ada yaitu tidak efektif dan efisiennya penyimpanan data karena hanya diarsipkan saja. Sehingga menyulitkan pencarian data, sering hilangnya bukti nota pembelian dan nota penjualan, lambatnya penyajian informasi yang diperlukan oleh pimpinan, selain itu proses pengolahan data dalam pembuatan laporan memakan waktu yang lama dan membutuhkan ketelitian yang tinggi dalam proses perhitungan. Untuk mendapatkan hasil yang optimal dalam pengolahan data yang cepat dan akurat maka diperlukannya komputer sebagai media atau alat untuk pencapaian hasil tersebut. Dengan menggunakan komputer, tingkat kecepatan serta ketelitian dan keamanan pun lebih terjamin, serta mempermudah dalam pencarian data.

\section{Pembahasan}

\section{Tinjauan Perusahaan}

Abadi Sport, yaitu sebuah usaha perdagangan yang menyediakan perlengkapan olahraga, didirikan oleh Bapak As'ari pada tanggal 5 juni 2009 yang beralamat di Jl. Raya Ps. Loji, Cintalaksana, Tegalwaru, Kabupaten Karawang, Jawa Barat. Kegiatan utamanya adalah membeli barang dagang dengan jumlah banyak untuk dijual kembali dengan harapan 
untuk mendapatkan keuntungan atau laba tanpa melakukan perubahan terhadap barang tersebut.

2. Use Case Diagram

a. Use case diagram login pengguna:

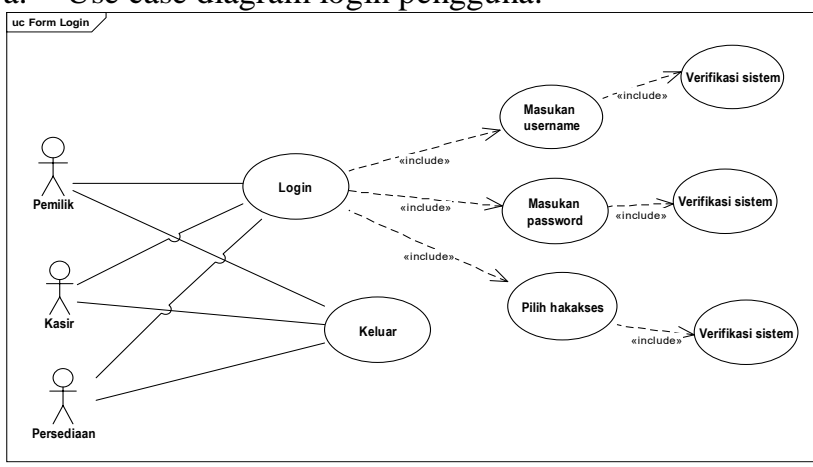

Gambar 2. Use Case Login

b. Use case diagram menu utama pemilik:

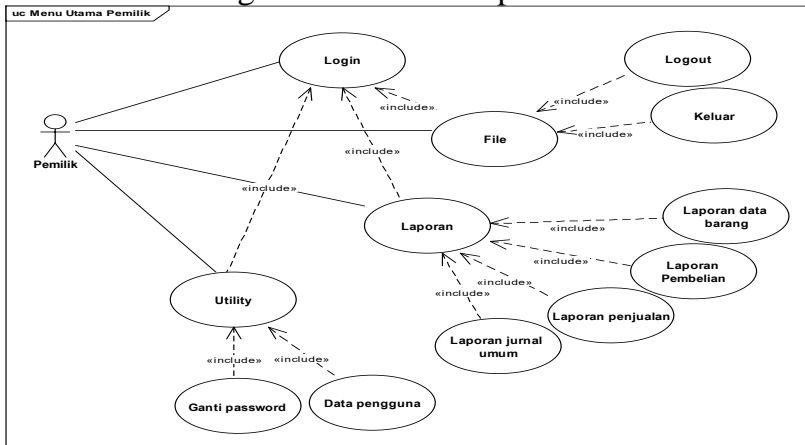

Gambar 3. Use Case Menu Pemilik

c. Use case diagram menu utama kasir:

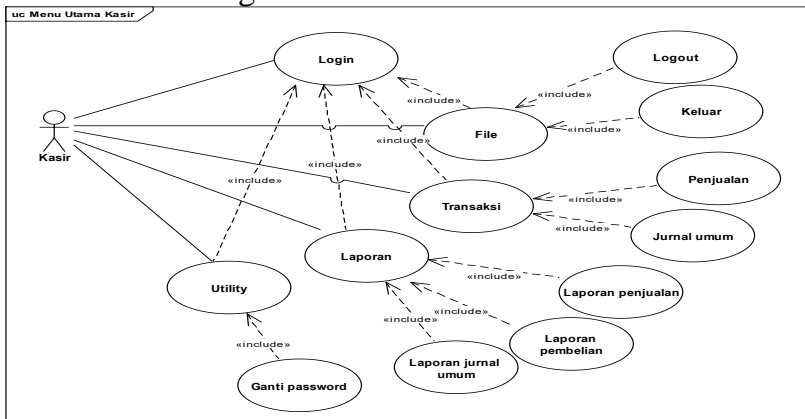

Gambar 3. Use Case Menu Pemilik

d. Use case diagram menu utama persediaan:

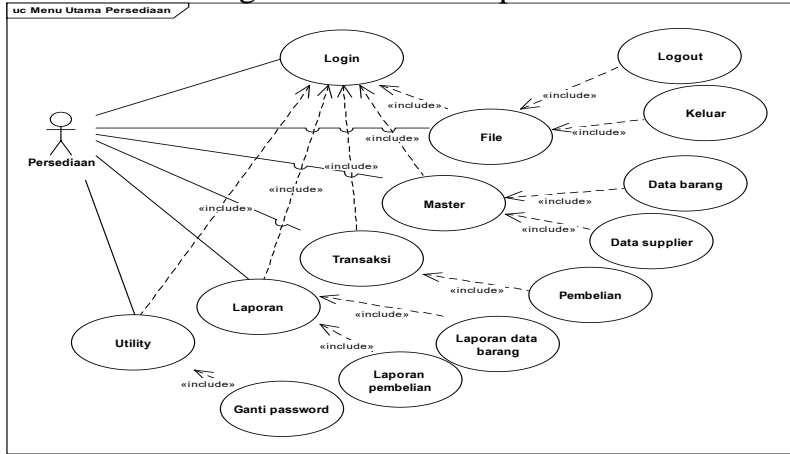

Gambar 4. Use Case Menu Persediaan

e. Use case diagram menu master data barang:

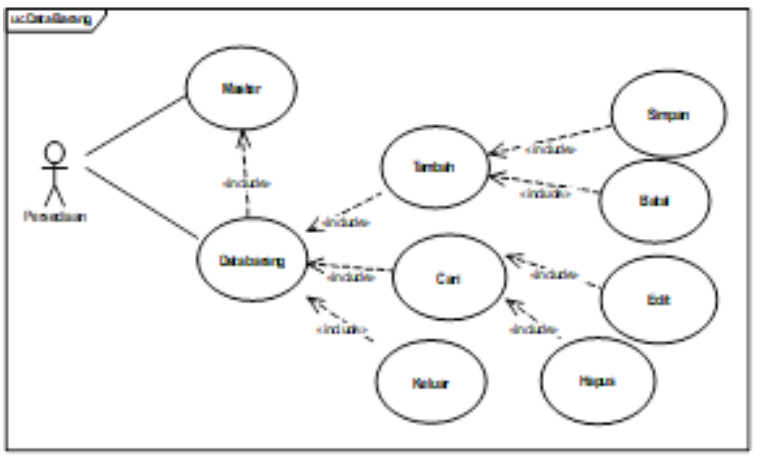

Gambar 5. Use Case menu Master Data Barang

f. Use case diagram menu transaksi pembelian:

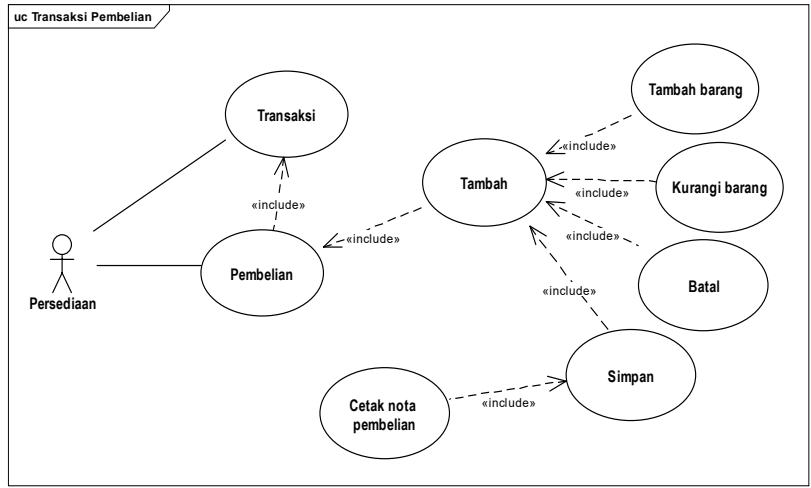

Gambar 6. Use Case Menu Master Data Barang

g. Use case diagram menu transaksi penjualan:

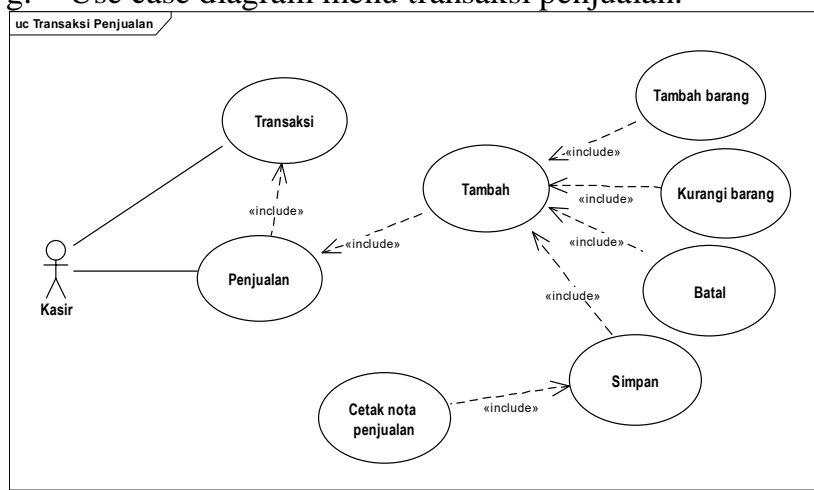

Gambar 7. Use Case Menu Transaksi Pembelian

h. Use case diagram menu transaksi penjualan: 


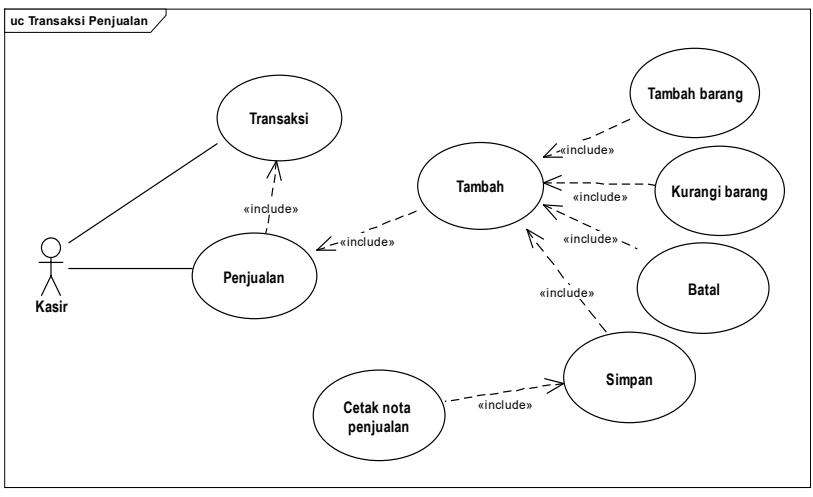

Gambar 8. Use Case Menu Transaksi penjualan

\section{Activity Diagram}

a. Login Pengguna:

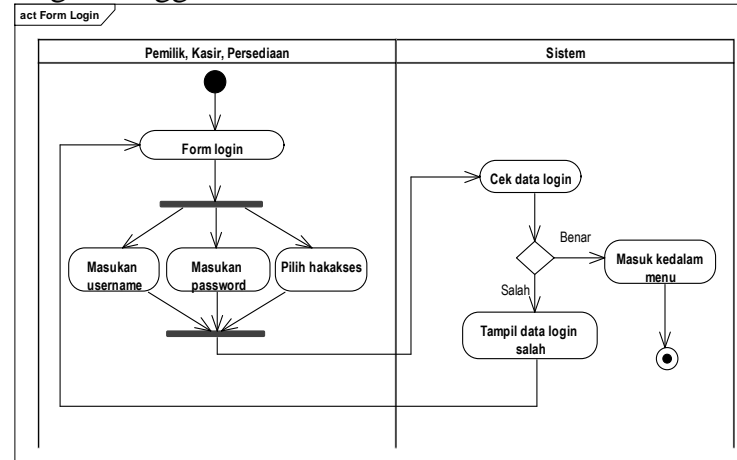

Gambar 9. Activity Diagram Login Pengguna

b. Menu Pemilik

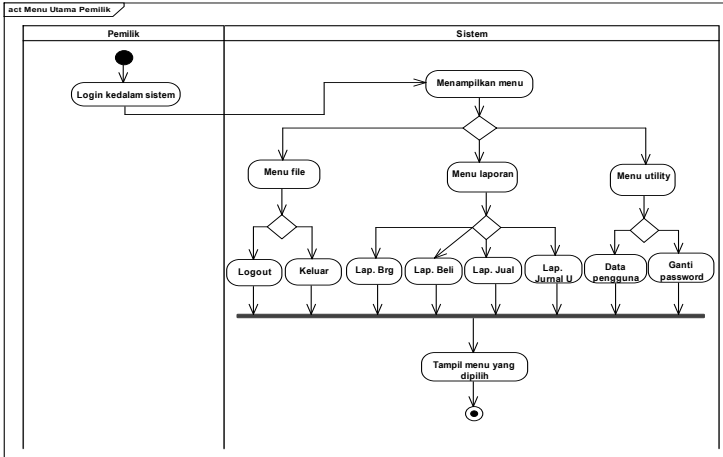

Gambar 10. Activity Diagram Menu Pemilik

c. Menu Kasir

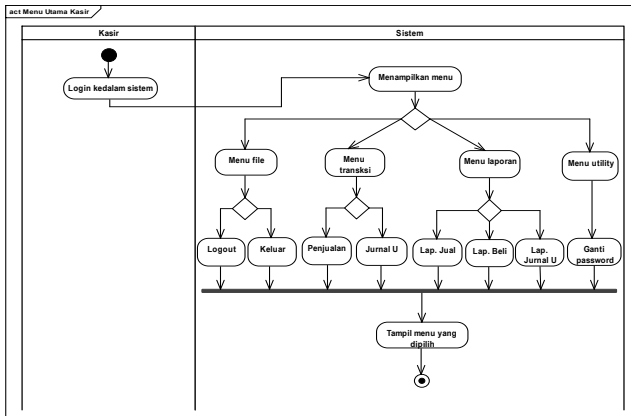

Gambar 11. Activity Diagram Menu Kasir d. Menu Persediaan

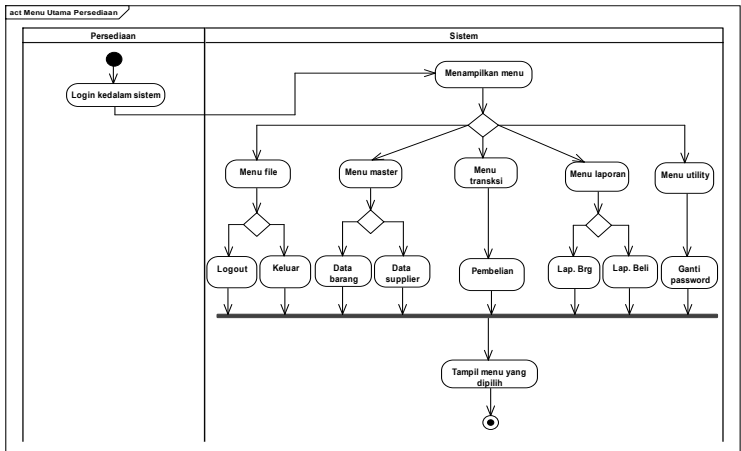

Gambar 12. Activity Diagram Menu Persediaan

e. Master Data Barang

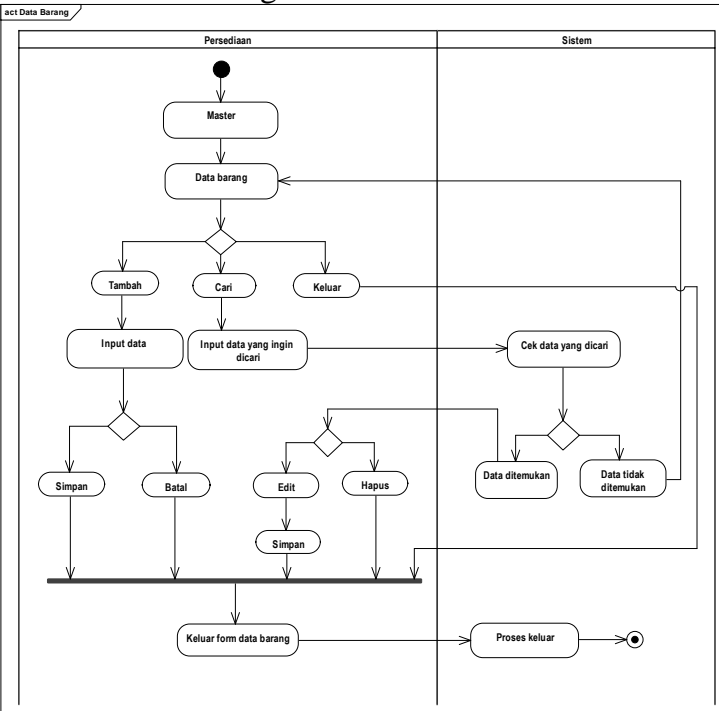

Gambar 13.Activity Diagram Master Data Barang

f. Menu Transaksi Pembelian

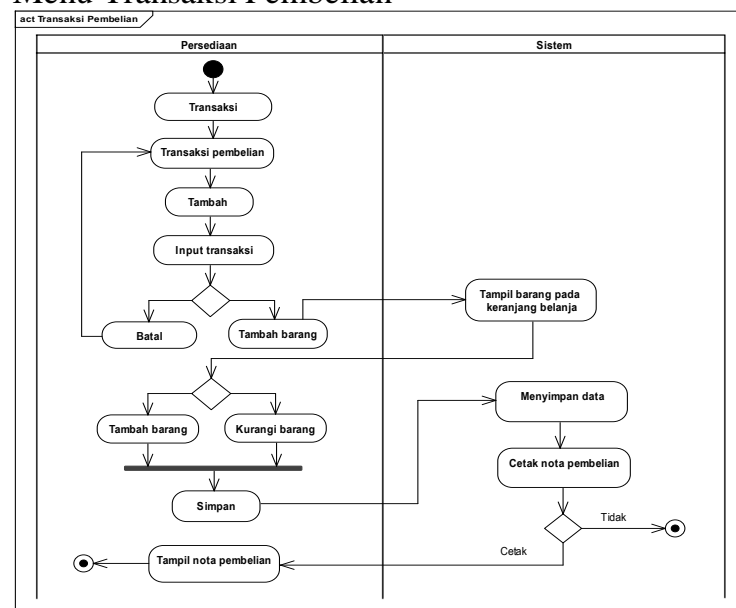

Gambar 14. Activity Diagram Transaksi Pembelian

g. Menu Transaksi Penjualan 


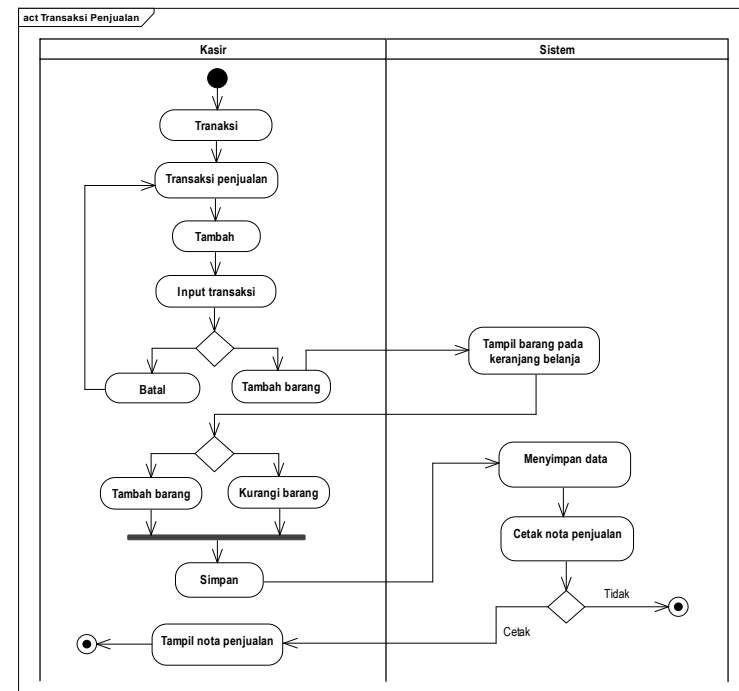

Gambar 15. Activity Diagram Transaksi Penjualan

4. Entity Relationship Diagram

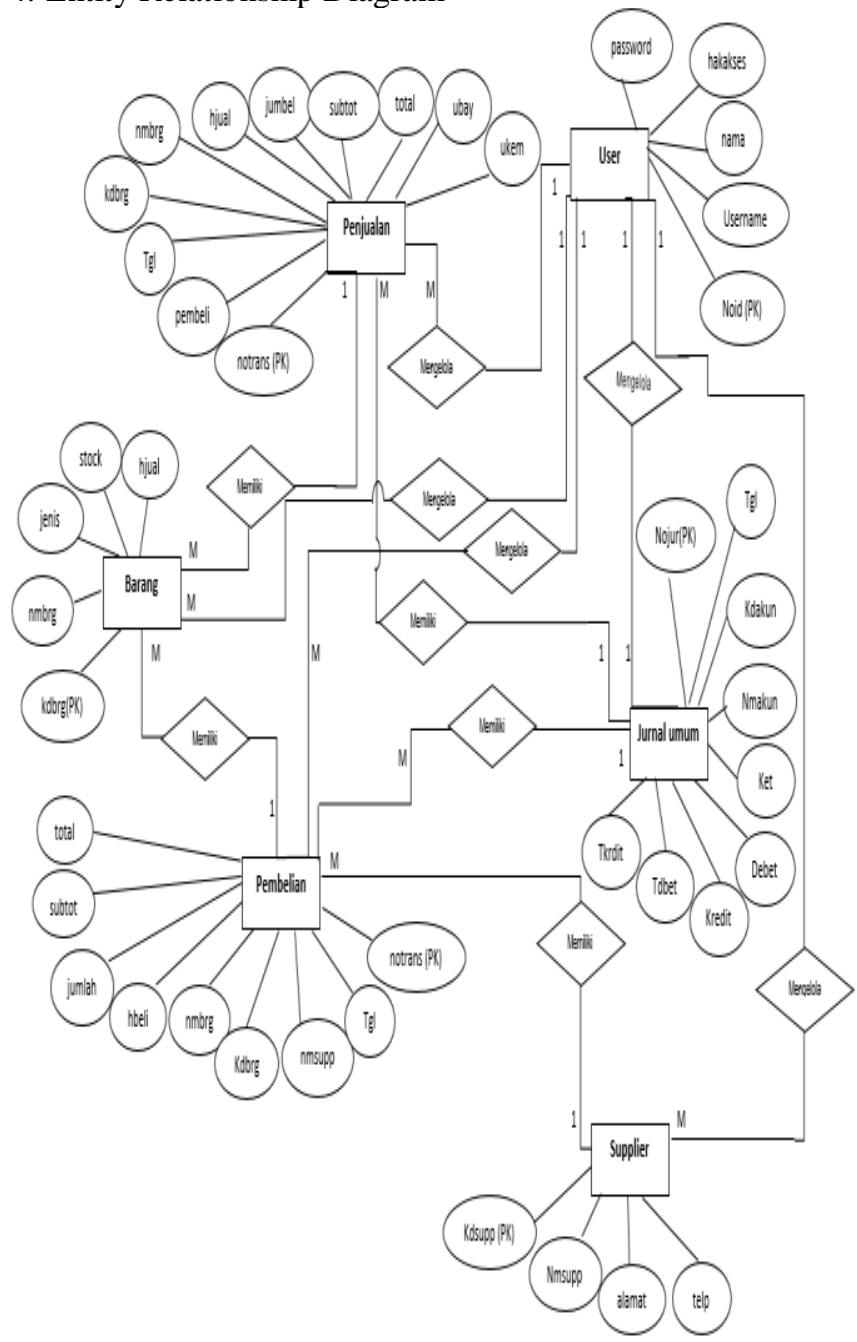

Gambar 16. Entity Relationship Diagram (ERD)

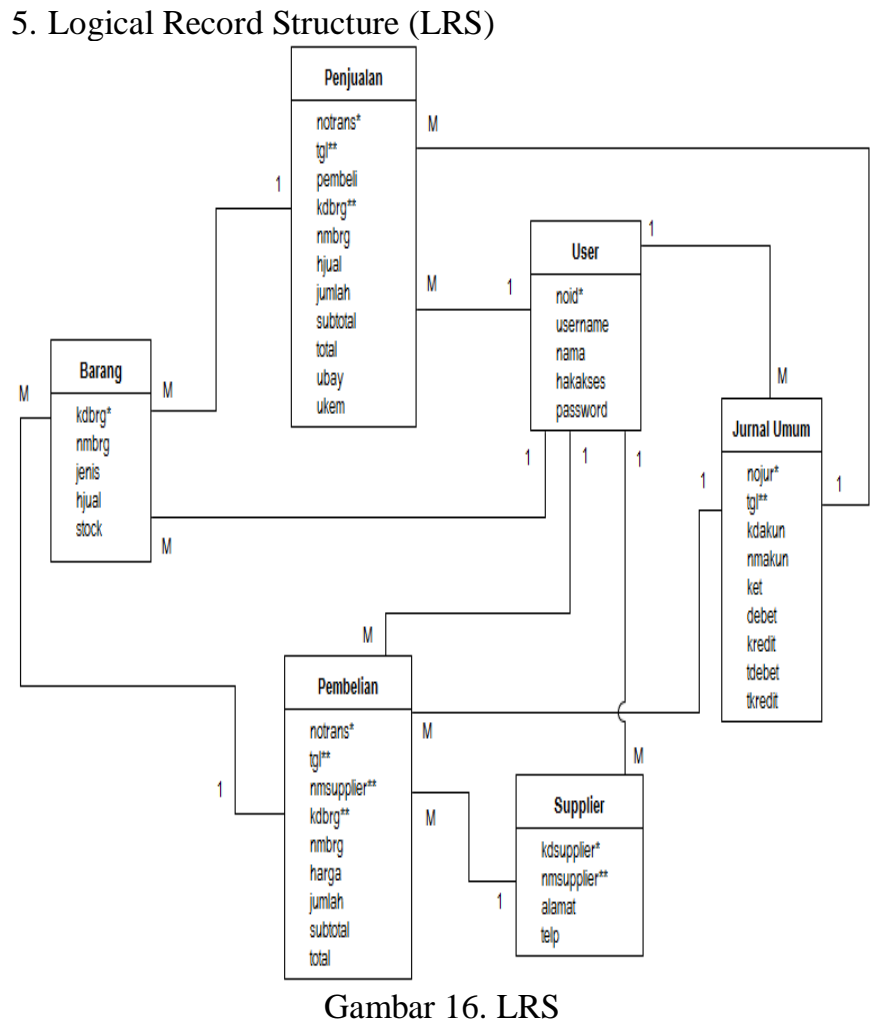

6. User Interface

a. Login Pengguna

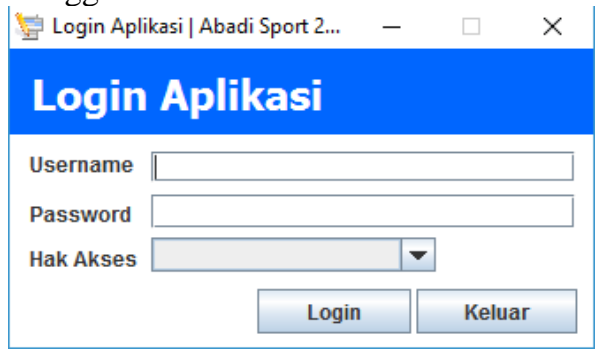

Gambar 17. User Interface Login Pengguna

b. Menu Utama Pemilik

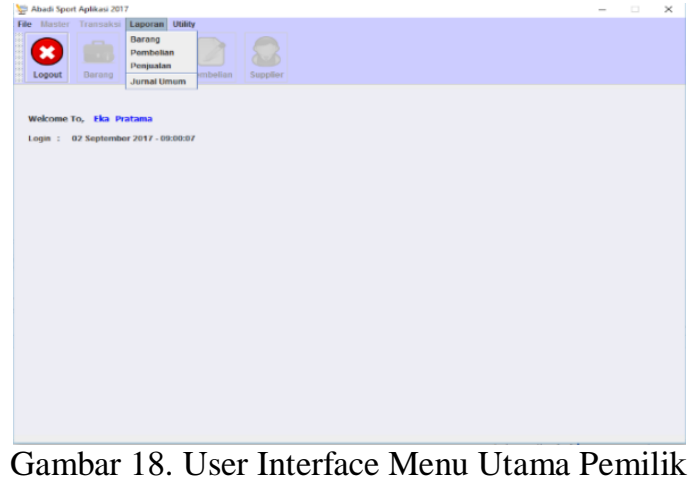

Gambar 18. User Interface Menu Utama Pemilik 
c. Menu Utama Kasir

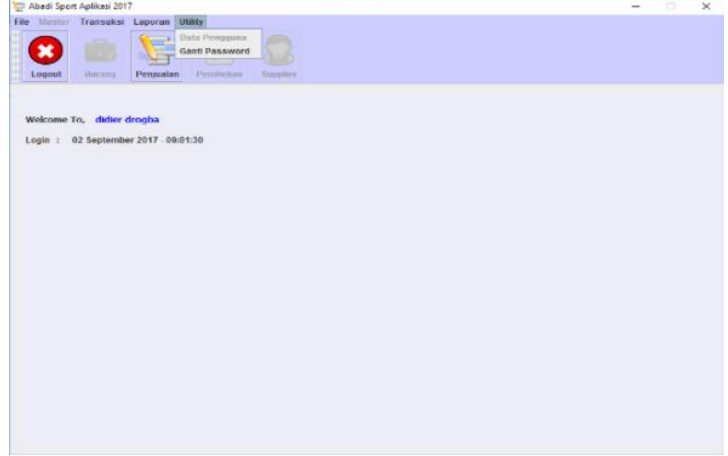

Gambar 19. User Interface Menu Utama Kasir

d. Menu Utama Persediaan

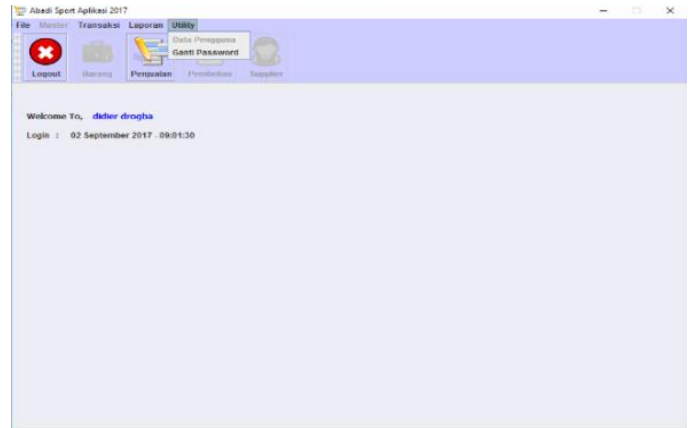

Gambar 20. User Interface Menu Utama Persediaan

e. Master Data Barang

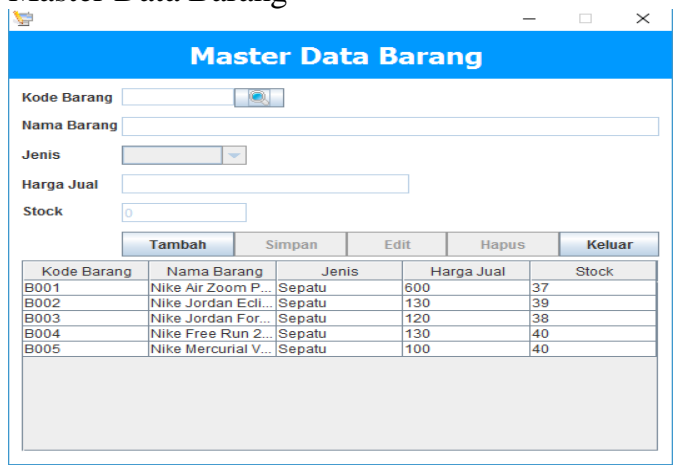

Gambar 21. User Interface master Data Barang

f. Transaksi Pembelian

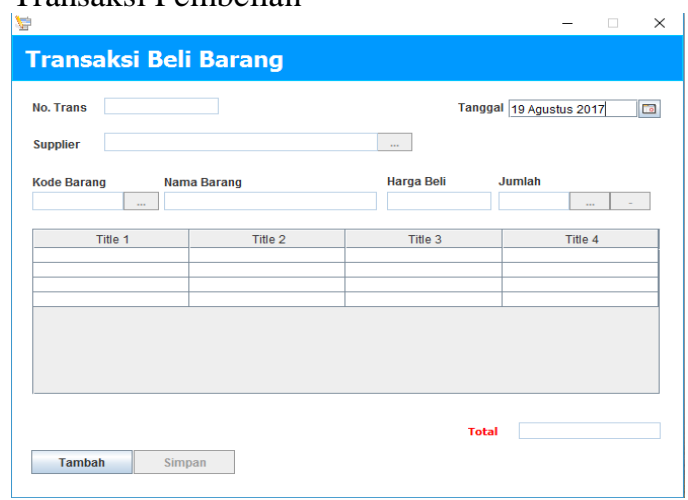

Gambar 22. User Interface Transaksi Pembelian g. Transaksi Penjualan

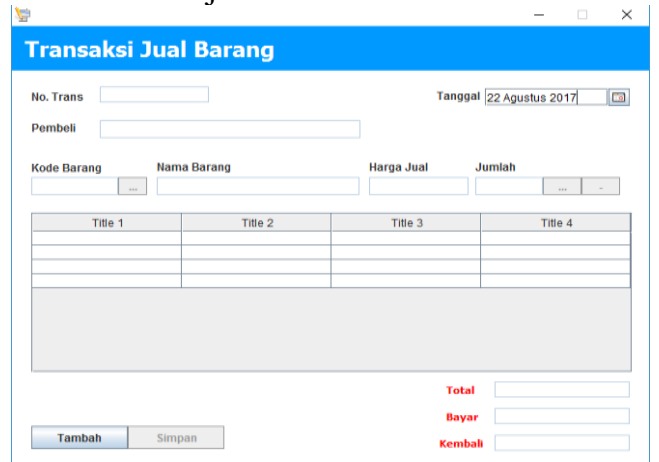

Gambar 23. User Interface Transaksi Penjualan

\section{Testing}

Proses pengujian perangkat lunak bertujuan untuk menjalankan sebuah program atau sistem untuk mencari kesalahan, pengujian yang dilakukan oleh penulis yaitu dengan menggunakan blackbox testing.

\begin{tabular}{|c|c|c|c|c|c|}
\hline $\begin{array}{l}N \\
o\end{array}$ & $\begin{array}{l}\text { Sekenario } \\
\text { Pengujian }\end{array}$ & Test Case & $\begin{array}{l}\text { Hasil yang } \\
\text { Diharapkan }\end{array}$ & $\begin{array}{c}\text { Hasil } \\
\text { Pengujia } \\
n\end{array}$ & $\begin{array}{l}\text { Kesi } \\
\text { puld }\end{array}$ \\
\hline 1 & $\begin{array}{l}\text { Pembeli, kode } \\
\text { barang, nama } \\
\text { barang, harga } \\
\text { jual, jumlah, } \\
\text { tidak diisi. } \\
\text { Lalu klik } \\
\text { tambah } \\
\text { barang }\end{array}$ & $\begin{array}{l}\text { Pembeli: } \\
\text { (kosong), } \\
\text { kode barang: } \\
\text { (kosong), } \\
\text { nama barang: } \\
\text { (kosong), } \\
\text { harga: } \\
\text { (kosong), } \\
\text { jumlah: } \\
\text { (kosong) }\end{array}$ & $\begin{array}{c}\text { Sistem akan } \\
\text { menolak, dan } \\
\text { tidak akan } \\
\text { ada data yang } \\
\text { disimpan } \\
\text { kedalam } \\
\text { keranjang } \\
\text { belanja }\end{array}$ & $\begin{array}{c}\text { Sesuai } \\
\text { harapan }\end{array}$ & $\begin{array}{l}\mathrm{Va} \\
\text { lid }\end{array}$ \\
\hline 2 & $\begin{array}{c}\text { Jumlah jual } \\
\text { diisi melebihi } \\
\text { stok barang } \\
\text { yang tersedia }\end{array}$ & $\begin{array}{c}\text { Jumlah jual: } \\
\text { (diisi lebih } \\
\text { besar dari } \\
\text { stok) }\end{array}$ & $\begin{array}{c}\text { Sistem akan } \\
\text { menolak dan } \\
\text { akan } \\
\text { menampilkan } \\
\text { pesan "stok } \\
\text { barang tidak } \\
\text { mencukupi" }\end{array}$ & $\begin{array}{c}\text { Sesuai } \\
\text { harapan }\end{array}$ & $\begin{array}{l}\mathrm{Va} \\
\text { lid }\end{array}$ \\
\hline 3 & $\begin{array}{c}\text { Kode barang, } \\
\text { nama barang, } \\
\text { harga jual, } \\
\text { jumlah diisi } \\
\text { kemudian } \\
\text { klik tambah } \\
\text { barang }\end{array}$ & $\begin{array}{l}\text { Kode barang: } \\
\text { (diisi), nama } \\
\text { barang: } \\
\text { (diisi), harga: } \\
\text { (diisi), } \\
\text { jumlah: } \\
\text { (diisi) }\end{array}$ & $\begin{array}{c}\text { Sistem akan } \\
\text { menbahkan } \\
\text { data yang } \\
\text { diisi kedalam } \\
\text { keranjang } \\
\text { belanja }\end{array}$ & $\begin{array}{c}\text { Sesuai } \\
\text { harapan }\end{array}$ & $\begin{array}{l}\mathrm{Va} \\
\text { lid }\end{array}$ \\
\hline 4 & $\begin{array}{c}\text { Pilih data } \\
\text { yang akan } \\
\text { dikurangi } \\
\text { pada } \\
\text { keranjang } \\
\text { belanja, } \\
\text { kemudian klik } \\
\text { kurangi } \\
\text { barang }\end{array}$ & $\begin{array}{c}\text { Salahsatu } \\
\text { data dalam } \\
\text { keranjang } \\
\text { belanja: } \\
\text { (dipilih) }\end{array}$ & $\begin{array}{c}\text { Sistem akan } \\
\text { menghapus } \\
\text { data yang } \\
\text { dipilih pada } \\
\text { keranjang } \\
\text { belanja }\end{array}$ & $\begin{array}{c}\text { Sesuai } \\
\text { harapan }\end{array}$ & $\begin{array}{l}\mathrm{Va} \\
\text { lid }\end{array}$ \\
\hline 5 & $\begin{array}{c}\text { Sistem akan } \\
\text { menampilkan } \\
\text { total harga } \\
\text { sesuai data } \\
\text { transaksi, lalu } \\
\text { uang bayar } \\
\text { diisi kurang } \\
\text { dari total }\end{array}$ & $\begin{array}{l}\text { Total harga: } \\
\text { (otomatis } \\
\text { terisi), uang } \\
\text { bayar: (diisi } \\
\text { kurang dari } \\
\text { total bayar) }\end{array}$ & $\begin{array}{c}\text { Sistem akan } \\
\text { menampilkan } \\
\text { pesan } \\
\text { “jumlah } \\
\text { bayar tidak } \\
\text { mencukupi” }\end{array}$ & $\begin{array}{c}\text { Sesuai } \\
\text { harapan }\end{array}$ & $\begin{array}{l}\text { Va } \\
\text { lid }\end{array}$ \\
\hline
\end{tabular}




\begin{tabular}{|c|c|c|c|c|c|}
\hline & harga & & & & \\
\hline 6 & $\begin{array}{l}\text { Sistem akan } \\
\text { menampilkan } \\
\text { total harga } \\
\text { sesuai data } \\
\text { transaksi, lalu } \\
\text { isikan uang } \\
\text { bayar }\end{array}$ & $\begin{array}{l}\text { Total harga: } \\
\text { (otomatis } \\
\text { terisi), uang } \\
\text { bayar: (diisi } \\
\text { lebih atau } \\
\text { sama dari } \\
\text { total bayar) }\end{array}$ & $\begin{array}{c}\text { Sistem akan } \\
\text { menampilkan } \\
\text { uang kembali } \\
\text { secara } \\
\text { otomatis }\end{array}$ & $\begin{array}{c}\text { Sesuai } \\
\text { harapan }\end{array}$ & $\begin{array}{l}\mathrm{Va} \\
\text { lid }\end{array}$ \\
\hline 7 & $\begin{array}{c}\text { Pembeli tidak } \\
\text { diisi, } \\
\text { keranjang } \\
\text { belanja terisi, } \\
\text { uang bayar, } \\
\text { uang kembali } \\
\text { tidak diisi }\end{array}$ & $\begin{array}{c}\text { Pembeli: } \\
\text { (kosong), } \\
\text { keranjang } \\
\text { belanja: } \\
\text { (terisi), uang } \\
\text { bayar: } \\
\text { (kosong), } \\
\text { uang } \\
\text { kembali: } \\
\text { (kosong) }\end{array}$ & $\begin{array}{c}\text { Sistem akan } \\
\text { menolak } \\
\text { untuk } \\
\text { menyimpan } \\
\text { data transaksi } \\
\text { penjualan } \\
\text { dan akan } \\
\text { menampilkan } \\
\text { pesan } \\
\text { "lengkapi } \\
\text { inputan } \\
\text { penjualan } \\
\text { barang” }\end{array}$ & $\begin{array}{c}\text { Sesuai } \\
\text { harapan }\end{array}$ & $\begin{array}{l}\text { Va } \\
\text { lid }\end{array}$ \\
\hline 8 & $\begin{array}{c}\text { Pembeli, } \\
\text { keranjang } \\
\text { belanja, uang } \\
\text { bayar, uang } \\
\text { kembali diisi }\end{array}$ & $\begin{array}{c}\text { Pembeli: } \\
\text { (diisi), } \\
\text { keranjang } \\
\text { belanja: } \\
\text { (terisi), uang } \\
\text { bayar: (diisi), } \\
\text { uang } \\
\text { kembali: } \\
\text { (diisi) }\end{array}$ & $\begin{array}{c}\text { Sistem akan } \\
\text { menyimpan } \\
\text { data transaksi } \\
\text { penjualan } \\
\text { kedalam } \\
\text { database }\end{array}$ & $\begin{array}{c}\text { Sesuai } \\
\text { harapan }\end{array}$ & $\begin{array}{l}\text { Va } \\
\text { lid }\end{array}$ \\
\hline 9 & $\begin{array}{c}\text { Setelah data } \\
\text { tersimpan } \\
\text { akan muncul } \\
\text { pesan cetak } \\
\text { nota } \\
\text { penjualan }\end{array}$ & $\begin{array}{c}\text { Cetak nota } \\
\text { penjualan: } \\
\quad(y a)\end{array}$ & $\begin{array}{c}\text { Sistem akan } \\
\text { menampilkan } \\
\text { nota } \\
\text { penjualan } \\
\text { sesuai } \\
\text { transaksi } \\
\text { yang dibuat }\end{array}$ & $\begin{array}{c}\text { Sesuai } \\
\text { harapan }\end{array}$ & \\
\hline $\begin{array}{l}1 \\
0\end{array}$ & $\begin{array}{c}\text { Setelah data } \\
\text { tersimpan } \\
\text { akan muncul } \\
\text { pesan cetak } \\
\text { nota } \\
\text { penjualan }\end{array}$ & $\begin{array}{c}\text { Cetak nota } \\
\text { penjualan: } \\
\text { (tidak) }\end{array}$ & $\begin{array}{c}\text { Sistem hanya } \\
\text { akan } \\
\text { menampilkan } \\
\text { pesan } \\
\text { "simpan } \\
\text { transaksi } \\
\text { berhasil" }\end{array}$ & $\begin{array}{c}\text { Sesuai } \\
\text { harapan }\end{array}$ & $\begin{array}{l}\text { Va } \\
\text { lid }\end{array}$ \\
\hline
\end{tabular}

\section{KESIMPULAN}

Setelah membuat rancangan program, bisa ditarik beberapa kesimpulan dan saran yang diberikan sebagai bagian akhir atau penutup dari tugas akhir ini, sebagai berikut:
Jurnal SISFOKOM, Volume 07, Nomor 01, Maret 2018

Program bertujuan untuk mempermudah pengelolaan transaksi agar lebih efisien dan akurat.

Penyimpanan data dalam database yang di ajukan akan meminimalkan akses kepada data fisik atau arsip. Dan hal ini berarti akan menghasilkan penyajian data atau informasi akan lebih cepat dan aman.

Perancangan program pengelolaan transaksi ini pimpinan bisa dengan cepat memperoleh laporan-laporan yang diinginkan berdasarkan periode tertentu sehingga dapat membantu dalam pembuatan-pembuatan keputusan.

\section{DAFTAR PUSTAKA}

[1] RachmatsyahAgus Dendi, Datia Merlini 2017 Perancangan Sistem Informasi Administrasi Surat Berbasis Desktop Pada Kantor Notaris Hoiril Masuli, Sh, M.KnJurnal SISFOKOM, Volume 06, Nomor 02, September 2017

[2] Harumy, T. Heny Febriana, Agus Perdana Windarto dan Indri Sulistianingsih. 2016. Belajar Dasar Algoritma dan Pemrograman C++. Yogyakarta: Deepublish.

[3] Irawati, Susan. 2008. Manajemen Keuangan. Bandung: PT. Pustaka.

[4] Simamora, Henry. 2015. Akuntansi Basis Pengambilan Keputusan Bisnis. Jakarta: Salemba Empat.

[5] Nugroho, Adi. 2010. Rekayasa Perangkat Lunak Berorientasi Objek dengan Metode USDP. Yogyakarta: Andi.

[6] Rosa dan Shalahuddin. 2013. Rekayasa Perangkat Lunak Terstruktur dan Berorientasi Objek. Bandung: Informatika.

[7] Yanto, Robi. 2016. Manajemen Basis Data Menggunakan MySQL. Yogyakarta: Deepublish.

[8] Kuryanti, Sandra J. 2016. Rancang Bangun Sistem E-Learning Sebaga Sarana Pembelajaran. Diambil dari: http://ejournal.bsi.ac.id/ejurnal/index.php/khatulistiwa/article/view/1260 /102 (27 April 2017).

[9] Afrizal. 2014. Metode Penelitian Kualitatif. Depok: PT. Rajagrafindo Persada.

[10] Chairunnisa, Connie. 2017. Metode Penelitian Ilmiah Aplikasi dalam Pendidikan dan Sosial. Jakarta: Mitra Wacana Media.

[11] Kurniawan, Hendra, Eri Mardiani, dan Nur Rahmansyah. 2011. Aplikasi Penjualan dengan Program Java Netbeans, Xampp, dan iReport. Jakarta: PT. Gramedia Pustaka Utama.

[12] Kurniawan, Yahya. 2008. Ngeblog dengan WordPress itu Gampang. Jakarta: PT. Media Elex Komputindo.

[13] Nofriadi. 2015. Java Fundamental dengan NetBeans 8.0.2. Yogyakarta: Deepublish

[14] Wicaksono, Yogi, dan SmitDev Community. 2008. Membangun Bisnis Online dengan Mambo. Jakarta: PT. Media Elex Komputindo. 